\title{
LITERASI SAINS SISWA MELALUI PENERAPAN MODEL PEMBELAJARAN BLENDED LEARNING DENGAN BLOG
}

\author{
Hana Lestari \\ Program Studi Guru Madrasah Ibtidaiyah Ilmu Tarbiyah dan Keguruan, Institut Agama Islam Sahid Bogor \\ Jl. Kapten Dasuki Bakri, Cibening, Kec. Pamijahan, Bogor, Jawa Barat 16810 \\ Email: hanabiologi@gmail.com, hana.lestari@inais.ac.id
}

Ridwan Siskandar

Program Studi Teknik Komputer, Sekolah Vokasi Institut Pertanian Bogor, Indonesia

Kampus IPB Cilibende, Jl kumbang no.14, kota Bogor, Jawa Barat

Email: ridwansiskandar@apps.ipb.ac.id, ridwansiskandar@gmail.com

\begin{abstract}
Abstrak
Penelitian ini bertujuan untuk mengetahui penerapan model pembelajaran blended learning dengan blog terhadap kemampuan literasi sains siswa pada pembelajaran IPA materi ekosistem di kelas V SD Negeri 1 Cibatok Kabupaten Bogor. Metode yang digunakan dalam penelitian ini adalah metode deskriptif. Sampel dari penelitian ini 52 orang siswa yang berasal dari 27 responden SDN 1 Cibatok dan 25 responden SDN 1 Cibatok. Teknik sampling yang digunakan adalah simple random sampling. Instrumen yang digunakan dalam penelitian ini adalah tes literasi sains siswa berisi 20 item pertanyaan. Hasil penelitian menunjukkan bahwa secara umum rata-rata kemampuan literasi sains siswa dari penerapan model pembelajaran blended learning dengan blog nilai rata-rata 74,83 dengan kategori baik. Maka dapat disimpulkan bahwa literasi sains siswa melalui penerapan model pembelajaran blended learning dengan blog sudah baik. Agar siswa memiliki pemahaman literasi sains yang lebih baik maka hendaknya dilatih terus menerus pemahaman siswa mengenai sains melalui pembelajaran model pembelajaran blended learning dengan blog.
\end{abstract}

Kata Kunci:

Kemampuan Literasi Sains; Model pembelajaran Blended learning dengan Blog.

\begin{abstract}
This research aimed to know the use the application of the learning model of blended learning with blogs to the ability of students' scientific literacy in learning science on ecosystem subconcept at $5^{\text {th }}$ grade elementary school. This research used descriptive method. The sample of this research was 52 students, 27 were from SDN 1 Cibatok, and the other 25 were from SDN 1 Cibatok. The sampling technique used was random technique. The science literacy test used consisted of 20 items. The instrument used in this research were assessment sheet and survey respon sheet for then test for science literacy. Based on the result showed students science literacy by the use of the learning model of blended learning with blogs was conducted 74,83 in categorized good. Then it can be concluded that student literacy through the application of blended learning models with blogs is already good. So that students have a better understanding of scientific literacy, students should be continuously trained to understand science learning model blended learning with blogs.
\end{abstract}

Keyword:

Learning Model of blended learning with blogs; Scientific literacy

\section{A. PENDAHULUAN}

Memasuki era revolusi industri 4.0, yaitu era dimana perkembangan ilmu pengetahuan yang pesat ditunjang oleh perkembangan teknologi menuju terbentuknya masyarakat digital. Masyarakat digital harus mampu memiliki keterampilan abad 21 seperti keterampilan untuk belajar secara mandiri (the ability to learn independently), etika dan tanggung jawab (ethics and responsibility), keterampilan komunikasi (communications skills), keterampilan berpikir (thinking skills; critical thinking, problem-solving, creativity, originality, strategizing), kerja tim dan fleksibelitas (teamwork and flexibility), serta keterampilan digital (digital skills) dan keterampilan literasi.

Literasi merupakan kemampuan membaca dan menghitung yang dikuasai oleh seseorang. Literasi tak hanya kemampuan seseorang dalam hal membaca dan menulis namun mencakup keterampilan literasi data, literasi teknologi dan literasi manusia. Literasi data terkait dengan kemampuan membaca, menganalisis dan membuat konklusi berpikir berdasarkan data dan informasi yang diperoleh. Literasi teknologi terkait dengan kemampuan memahami cara kerja mesin, aplikasi teknologi dan bekerja berbasis produk teknologi untuk mendapatkan hasil maksimal. Literasi manusia diantaranya 
keterampilan literasi sains, bahasa dan numeric yang melatih kemampuan komunikasi, kolaborasi, berpikir kritis, kreatif dan inovatif.

Literasi sains merupakan kemampuan menggunakan pengetahuan sains, pemahaman tentang konsep-konsep ilmiah, mengidentifikasi pertanyaan dan menarik kesimpulan berdasarkan bukti dalam rangka memahami serta mengambil keputusan berkenaan dengan alam dan perubahan yang dilakukan terhadap alam melalui manusia. Literasi sains sangat penting untuk mempersiapkan bekal keterampilan yang harus dimiliki siswa di abad ke 21 dari tingkat sekolah dasar sampai perguruan tinggi yang meliputi keterampilan berpikir kritis, kreatif, kolaboratif dan komunikasi. Kemampuan literasi sains siswa dapat dikembangkan dan ditingkatkan dengan metode yang tepat dan didukung oleh teknologi yang memadai.

Teknologi dalam pembelajaran merupakan elemen yang perlu untuk dihadirkan dalam kegiatan sehari-hari di sekolah sebagai cara baru dalam mempelajari pengetahuan dan proses belajar dan mengajar untuk mengembangkan kemampuan literasi sains siswa. Hal tersebut sejalan dengan program Pemerintah yang dituangkan dalam Permendikbud No. 65 Th. 2013 tentang Standar Proses Pendidikan Dasar dan Menengah yang antara lain disebutkan penggunaan prinsip pembelajaran "pemanfaatan TIK untuk meningkatkan efisiensi dan efektivitas pembelajaran". Dalam suatu proses pembelajaran terdapat dua unsur penting yang dapat mempengaruhi efisiensi, efektifitas dan hasil pembelajaran yakni model pembelajaran dan media pembelajaran. Kedua aspek ini saling berkaitan. Pemilihan model pembelajaran akan mempengaruhi jenis media pembelajaran yang digunakan.

Dalam mengembangkan literasi sains siswa, guru ditantang untuk memadukan model pembelajaran dan kemajuan teknologi informasi untuk mengimbangi gaya belajar siswa yang beragam. Model-model pembelajaran yang dirancang sedapat mungkin berjalan selaras dengan perkembangan teknologi karena pemilihan model pembelajaran sangat berpengaruh terhadap tingkat keberhasilan belajar siswa. Keberhasilan penggunaan model pembelajaran tergantung oleh kemampuan guru dalam mengevaluasi materi pembelajaran dan kemampuan mengkreasikan materi tersebut kedalam media berbasis teknologi. Salah satu model pembelajaran yang dapat diterapkan untuk mengembangkan kemampuan literasi sains siswa melalui penggunaan media berbasis teknologi adalah model blended learning.

Blended learning merupakan pembelajaran yang mengkombinasikan atau menggabungkan antara pembelajaran online dan face-to-face (pembelajaran tatap muka) dengan menggunakan berbagai teknologi berbasis web, teknologi $e$ learning dan multimedia, seperti video streaming, virtual class, animasi teks online dikombinasikan dengan bentuk tradisional pelatihan di kelas dan pelatihan perorangan. Blended Learning menggunakan teknologi informasi dan komunikasi dalam aktivitas tatap muka, baik menggunakan jejaring terikat (web-dependent) maupun sebagai jejaring pelengkap (websupplemented) digunakan sebagai suatu alternatif jenis pembelajaran yang efektif, efisien dan menunjang sarana learning community bagi siswa karena dalam blended learning terdapat interaksi sosial yang memungkinkan siswa dapat mempersepsikan diri mereka sebagai sebuah komunitas yang saling bergantung secara positif. Penerapan model pembelajaran blended learning diperlukan tools atau media berbasis teknologi yang dapat mendukung penerapan model pembelajaran blended learning. Dengan berkembangnya teknologi web 2.0 merubah karakteristik web menjadi lebih dinamis dan interaktif sehingga melahirkan banyak platform UGC (user generated content) yang memungkinkan penggunanya untuk dapat mereuse, reshare, dan recreate konten-konten sesuai kebutuhan. Salah satu platform yang mendukung kegiatan tersebut adalah blog atau weblog. Melalui blog atau weblog yang digunakan dalam pembelajaran, siswa dapat mengakses informasi belajar dan meningkatkan keterampilan teknologinya, berbagi dan menggunakan ulang konten-konten pembelajaran. Blog dapat membantu siswa meningkatkan kemampuan berpikir kritis, kemampuan literasi sains, kemampuan menulis, dan memudahkan siswa dan pendidik untuk dapat berinteraksi dan berkolaborasi secara global melalui berbagai fitur dan sumber informasi yang dapat mendukung proses pembelajaran. Dengan demikian, penggunaan blog untuk mendukung penerapan model pembelajaran blended learning dapat dilakukan.

Model pembelajaran blended learning dengan media blog dapat membantu siswa untuk berkembang lebih baik di dalam proses belajar, sesuai dengan gaya belajar dan preferensi dalam belajar juga menyediakan peluang bagi guru dan 
siswa untuk pembelajaran secara mandiri dan terus berkembang. Melalui model pembelajaran blended learning dengan media blog dapat dilakukan penjadwalan fleksibilitas bagi siswa, dengan menggabungkan aspek terbaik dari tatap muka dan instruksi online. Kelas tatap muka dapat digunakan untuk melibatkan para siswa dalam pengalaman interaktif. Sedangkan porsi online memberikan siswa dengan konten multimedia yang kaya akan pengetahuan pada setiap saat, dan di mana saja melalui akses Internet baik di dalam kelas maupun di luar kelas. Materi pembelajaran yang disampaikan melalui blog digunakan sebagai bahan pengayaan pada pembelajaran konvensional atau pada saat tatap muka, sebagai bahan diskusi atau sesi tanya jawab di kelas.

Model pembelajaran blended learning dengan blog memiliki tiga tahapan yaitu (1) Seeking of information, pencarian informasi dari berbagai sumber informasi yang tersedia secara online maupun offline dengan berdasarkan pada relevansi, validitas, reliabilitas konten dan kejelasan akademis; (2) Acquisition of information menemukan, memahami, serta mengkonfrontasikannya dengan ide atau gagasan yang telah ada dalam pikiran kemudian menginterpretasikan informasi/pengetahuan dari berbagai sumber yang tersedia, sampai mereka mampu mengkomunikasikan kembali dan menginterpretasikan ide-ide dan hasil interpretasinya menggunakan fasilitas online/offline; (3) Synthesizing of knowledge, mengkonstruksi/merekonstruksi pengetahuan melalui proses asimilasi dan akomodasi bertolak dari hasil analisis, diskusi dan perumusan kesimpulan dari informasi yang diperoleh. Kembali dan menginterpretasikan ide-ide dan hasil interpretasinya menggunakan fasilitas online/offline.

Beberapa penelitian menjelaskan bahwa penerapan model pembelajaran blended learning dalam kegiatan pembelajaran di sekolah menunjukkan peningkatan positif terhadap kemampuan literasi sains siswa. Di SMP 2 Surakarta penerapan model pembelajaran blended learning dengan menggunakan media Moodle pada pembelajaran IPA terpadu dengan tema Pelestarian Lingkungan menunjukkan peningkatan kemampuan literasi sains siswa. Sementara di SMA Negeri 3 Wonosari, implementasi model pembelajaran blended learning dengan memadukan pembelajaran tatap muka di kelas dan secara online menggunakan $e$ learning dapat meningkatkan kemandirian belajar dan literasi sains siswa pada mata pelajaran Sistem peredaran darah kelas XI. Alwan (2017) melakukan penelitian tentang penerapan model pembelajaran blended learning dengan aplikasi edmodo pada siswa kelas XI melalui peningkatan literasi sains siswa dari 55,29 menjadi 88,65 dan respon siswa secara umum menanggapi positif.

Berdasarkan penelitian yang sudah dipaparkan tersebut, belum ada penelitian yang menerapkan model pembelajaran blended learning dengan blog di Sekolah Dasar (SD). Sedangkan kemampuan literasi sains perlu dikembangkan sejak dini dari usia sekolah dasar, sehingga terkontruks pengetahuan dan pemahaman siswa tentang sains yang berkaitan dengan konten sains, produk sains, serta prosesproses kerja ilmiah untuk memahami fenomena sains yang ada dan menumbuhkan keterampilan berpikir tingkat tinggi. Oleh karena itu penelitian ini menjadi penting adanya. Atas dasar hal-hal tersebut diatas mendorong ketertarikan untuk menganalisis dan mengkaji profil literasi sains siswa melalui pembelajaran blended learning dengan media blog pada pembelajaran IPA materi ekosistem di Sekolah Dasar.

Penelitian berlangsung di SDN 1 Cibatok dan SDN 2 Cibatok Semester Ganjil 2018/2019. Populasi dari penelitian ini adalah siswa SD Kelas 5 SDN 1 Cibatok dan SDN 2 Cibatok. Sampel dari penelitian ini 52 orang siswa yang berasal dari 27 responden SDN 1 Cibatok dan 25 responden SDN 1 Cibatok. Teknik sampling yang digunakan adalah simple random sampling. Penelitian ini menggunakan rancangan penelitian deskriptif. Dalam penelitian ini untuk mendeskripsikan (memaparkan) proses pembelajaran menggunakan model blended learning dengan blog. Kemampuan literasi sains akan diukur melalui pemberian instrumen literasi sains siswa berupa tes. Tes literasi sains diukur kevalidan dan reliabilitasnya menggunakan rumus Cronbach's Alpha dan dianalisis secara deskriptif.

Dalam penelitian ini metode yang digunakan adalah metode deskriptif. Sampel dari penelitian ini 52 orang siswa yang berasal dari 27 responden SDN 1 Cibatok dan 25 responden SDN 1 Cibatok. Teknik sampling yang digunakan adalah simple random sampling. Instrumen yang digunakan dalam penelitian ini adalah tes literasi sains siswa berisi 20 item pertanyaan. Adapun tujuan penelitiannya yaitu untuk mengetahui penerapan model pembelajaran blended learning dengan blog terhadap kemampuan literasi sains 
siswa pada pembelajaran IPA materi ekosistem di kelas V SD Negeri 1 Cibatok Kabupaten Bogor.

Pengembangan instrumen tes literasi sains dalam penelitian ini dilakukan oleh peneliti melalui proses kajian secara teoritik tentang substansi yang akan diukur. Adapun kisi-kisi literasi sains siswa diamati pada Tabel 1.

Tabel 1. Kemampuan Kisi-Kisi Literasi Sains Siswa

\begin{tabular}{|c|c|c|}
\hline No & $\begin{array}{c}\text { Kompetensi Ilmiah yang } \\
\text { Diukur dalam Literasi Sains }\end{array}$ & Indikator \\
\hline 1. & $\begin{array}{l}\text { Mengidentifikasi } \quad \text { isu-isu } \\
\text { (masalah) ilmiah }\end{array}$ & $\begin{array}{l}\text { Mengidentifikasi pendapat ilmiah yang valid (misalnya } \\
\text { pendapat/teori untuk mendukung hipotesis) }\end{array}$ \\
\hline \multirow[t]{4}{*}{2.} & \multirow[t]{4}{*}{ Menjelaskan fenomena ilmiah } & $\begin{array}{l}\text { Melakukan penelusuran literatur yang efektif (misalnya } \\
\text { mengevaluasi validitas sumber dan membedakan antara tipe } \\
\text { sumber-sumber tersebut) }\end{array}$ \\
\hline & & Membuat grafik secara tepat dari data \\
\hline & & $\begin{array}{l}\text { Memecahkan masalah menggunakan keterampilan kuantitatif, } \\
\text { termasuk statistik dasar (misalnya menghitung rata-rata, } \\
\text { probabilitas, persentase, frekuensi) }\end{array}$ \\
\hline & & 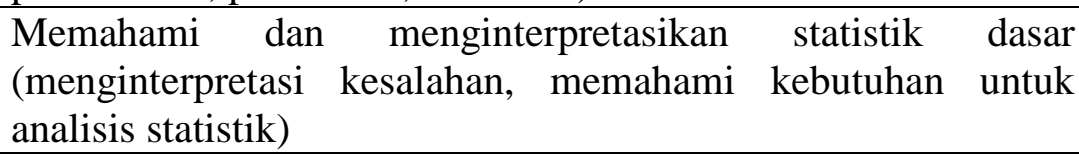 \\
\hline 3. & Menggunakan bukti ilmiah & $\begin{array}{l}\text { Melakukan inferensi, prediksi, dan penarikan kesimpulan } \\
\text { berdasarkan data kuantitatif }\end{array}$ \\
\hline
\end{tabular}

\section{B. HASIL DAN PEMBAHASAN}

Penelitian penggunaan model pembelajaran blended learning dengan blog pada pembelajaran IPA materi ekosistem di SDN 1 Cibatok dan SDN 2 Cibatok. Berdasarkan hasil data yang diperoleh setelah siswa belajar menggunakan model pembelajaran blended learning dengan blog, literasi sains mencapai nilai rata-rata 70,83 kategori baik. Data hasil penelitian ini diperoleh melalui tes literasi sains siswa yang diberikan pada akhir pertemuan. Tes literasi sains berupa pertanyaan berjumlah 20 butir pernyataan. Berdasarkan hasil olah data tes literasi sains siswa, dari enam indikator lima diantaranya berada dalam kategori baik sedangkan dua indikator berada pada kategori cukup (gambar 1).

Kemampuan Literasi Sains Siswa Pada Setiap Indikator (\%)

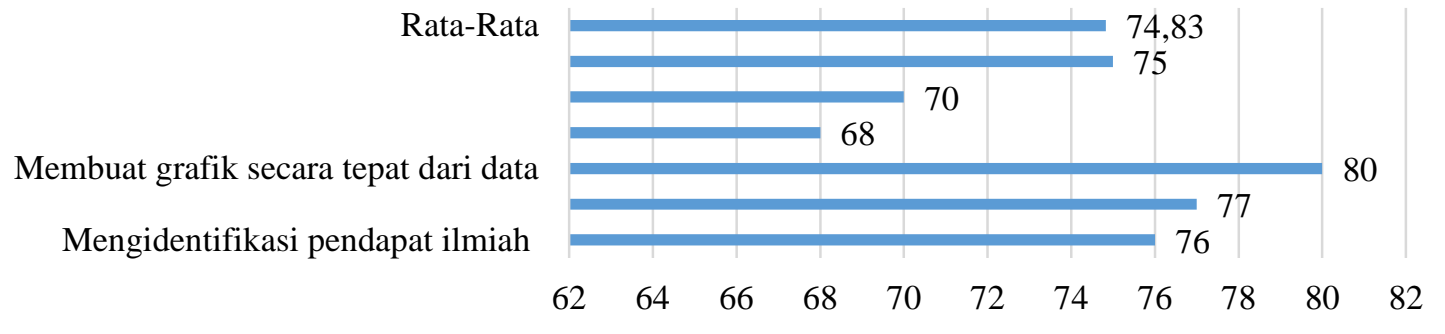

Gambar 1. Distribusi Skor Rata-rata Persentase Kemampuan Literasi Sains Siswa

Hasil analisis menunjukkan bahwa kemampuan literasi sains siswa dengan persentase tertinggi $80 \%$ adalah membuat grafik secara tepat dari data dan persentase terendah $68 \%$ adalah kemampuan memecahkan masalah. Setiap indikator kemampuan literasi sains siswa dikembangkan melalui pembelajaran blended learning dengan blog. Pembelajaran ini menerapkan gabungan pembelajaran tatap muka berbasis nature of sains (NOS) dan pembelajaran online dengan blog. Blended learning dengan blog memiliki tiga tahapan yaitu tahapan pertama yakni Seeking of information; pada tahap ini siswa mengembangkan pengetahuan sains siswa dari aspek sosial, budaya atau tata nilai masyarakat melalui kegiatan online dimana siswa mempelajari dan mencari referensi dari berbagai sumber yang terkait dengan topik sains yang 
sedang up to date di masyarakat yang telah ditentukan (di blog guru, buku atau website), kemampuan literasi sains yang dilatih adalah kemampuan melakukan penelusuran literatur yang efektif dengan persentase $77 \%$ artinya siswa sudah baik dalam membaca dan menelusuri literatur terkait dengan topik yang dipelajari serta indikator mengidentifikasi pendapat ilmiah dengan presentase $76 \%$ artinya siswa sudah cukup baik dalam memahami pendapat ilmiah yang membangun materi yang dipelajari.

Tahap kedua yakni Acquisition of information; pada tahap ini siswa mengembangkan sikap empiris dengan melakukan pengamatan, diskusi dengan etos kerja dan kreativitas melalui kegiatan secara offline yaitu melakukan pengamatan mengenai topik yang sedang dipelajari (topic diberikan oleh guru untuk masing-masing kelompok), siswa merumuskan masalah mengajukan hipotesis, dan menuliskan cara kerja, mencatat data hasil pengamatan, menyimpulkan hasil pengamatan dan menyimpulkan hasil pengamatan serta secara online siswa merekam kegiatan pengamatan dan mengunggahnya di blog dan hasil diskusi kelompok di kirim ke blog guru dan siswa diberi kesempatan untuk menanggapi hasil diskusi melalui kolom komentar guru, pada tahap ini kemampuan literasi sains yang dilatih adalah memahami dan menginterpretasikan statistic dasar, membuat grafik secara tepat dari data, memecahkan masalah. Untuk indikator literasi sains memahami dan menginterpretasikan statistik dasar dengan persentase $70 \%$ artinya kemampuan siswa cukup dalam menginterpretasikan statistik dasar dari hasil pengamatan. Indikator membuat grafik secara tepat dari data dengan persentase $80 \%$ artinya siswa sudah baik dalam membuat grafik dari hasil pengamatan yang diperoleh saat kegiatan observasi dan diskusi. Indikator memecahkan masalah dengan persentase 68\% artinya siswa belum cukup baik dalam memecahkan permasalahan dari hasil diskusi, pengamatan dan observasi yang dilakukan.

Tahap ketiga yakni Synthesizing Knowledge; pada tahap ini siswa bekerjasama dan berkolaborasi untuk mempresentasikan hasil diskusi kelompok ke depan kelas dan Siswa dan guru bersama-sama menyimpulkan materi yang dipelajari pada pembelajaran ini pada kegiatan tatap muka serta siswa mengunggah hasil akhir diskusi presentasi dan simpulan hasil pembelajaran ke blog guru secara online, pada tahap ini kemampuan literasi sains siswa yang dilatih adalah melakukan inferensi, prediksi dan penarikan kesimpulan dan mendapat persentase sebesar $75 \%$ yang artinya siswa sudah cukup baik dalam menarik kesimpulan hasil dari diskusi dan pengamatan.

Pembelajaran Blended learning dengan blog diterapkan di dua sekolah dasar negeri untuk menggambarkan kemampuan literasi sains siswa. Adapun kemampuan literasi sains siswa di SDN Cibatok 1 dan di SDN Cibatok 2 dapat diamati pada Gambar 2.

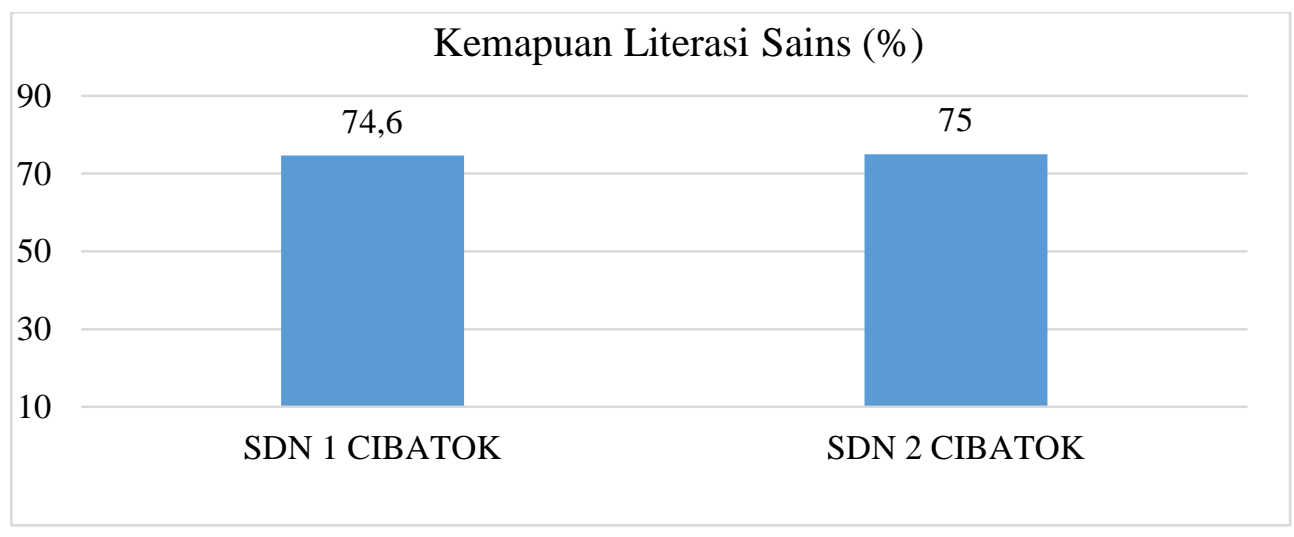

Gambar 2. Distribusi Skor Rata-rata Persentase Kemampuan Literasi Sains

Dari Gambar 2 menjelaskan bahwa kemampuan literasi sains siswa berdasarkan Sekolah menunjukkan bahwa SDN 1 Cibatok $74,6 \%$ (Baik) dan SDN 2 Cibatok memperoleh $75 \% \quad$ (Baik). Berdasarkan kriterianya menunjukkan bahwa kedua sekolah tersebut berada pada kategori baik, artinya tidak ada perbedaan siswa di SDN 1 Cibatok dengan SDN 2
Cibatok terhadap kemampuan literasi sains siswa. Maka dapat disimpulkan bahwa rata-rata kemampuan literasi sains siswa dengan penerapan model blended learning dengan blog berada pada kategori baik. Hal ini pun digambarkan dengan data respon siswa tentang model pembelajaran blended learning dengan blog tersaji dalam tabel 
2. Hasil penelitian menunjukkan rata-rata respon sebesar $85.23 \%$ dengan kategori sangat baik.

Tabel 2. Respon terhadap model pembelajaran blended learning dengan blog

\begin{tabular}{|c|c|c|}
\hline Tahapan & Persentase & Kategori \\
\hline \multicolumn{3}{|l|}{ Seeking of information } \\
\hline \multicolumn{3}{|l|}{ Offline } \\
\hline $\begin{array}{c}\text { Siswa mendapatkan apersepsi dari guru terkait } \\
\text { materi yang akan dipelajari. }\end{array}$ & 88,87 & Sangat Baik \\
\hline $\begin{array}{c}\text { Guru mengajukan pertanyaan-pertanyaan } \\
\text { mendalam terkait artikel (topik sains) yang telah } \\
\text { dibaca siswa } \\
\text { Siswa mencoba menjawab pertanyaan yang } \\
\text { diajukan oleh guru terkait materi }\end{array}$ & 92,96 & Sangat Baik \\
\hline \multicolumn{3}{|l|}{ Online } \\
\hline $\begin{array}{l}\text { Siswa mempelajari dan mencari referensi dari } \\
\text { berbagai sumber yang terkait dengan topik sains } \\
\text { yang sedang up to date di masyarakat yang telah } \\
\text { ditentukan (di blog guru, buku atau website) }\end{array}$ & 86,90 & Sangat Baik \\
\hline $\begin{array}{c}\text { Siswa memberi tanggapan melalui kolom } \\
\text { komentar. }\end{array}$ & 87,90 & Sangat Baik \\
\hline \multicolumn{3}{|l|}{ Acquisition of information } \\
\hline \multicolumn{3}{|l|}{ Offline } \\
\hline $\begin{array}{l}\text { Siswa dibagi menjadi beberapa kelompok, siswa } \\
\text { melakukan pengamatan mengenai topik yang } \\
\text { sedang dipelajari (topic diberikan oleh guru untuk } \\
\text { masing-masing kelompok) } \\
\text { Siswa merumuskan masalah mengajukan hipotesis, } \\
\text { dan menuliskan cara kerja }\end{array}$ & 86,92 & Sangat Baik \\
\hline Siswa mencatat data hasil pengamatan & 85,86 & Sangat Baik \\
\hline Siswa menyimpulkan hasil pengamatan & 88,97 & Sangat Baik \\
\hline $\begin{array}{l}\text { Siswa mendiskusikan dan mengelaborasi hasil } \\
\text { pengamatan secara berkelompok }\end{array}$ & 86,90 & Sangat Baik \\
\hline \multicolumn{3}{|l|}{ Online } \\
\hline $\begin{array}{c}\text { Siswa merekam kegiatan pengamatan dan } \\
\text { mengunggahnya di blog guru }\end{array}$ & 83,82 & Sangat Baik \\
\hline $\begin{array}{l}\text { Hasil diskusi kelompok di kirim ke blog guru dan } \\
\text { siswa diberi kesempatan untuk menanggapi hasil } \\
\text { diskusi melalui kolom komentar guru. }\end{array}$ & 79,82 & Baik \\
\hline \multicolumn{3}{|l|}{ Synthesizing Knowledge } \\
\hline \multicolumn{3}{|l|}{ Offline } \\
\hline $\begin{array}{l}\text { Siswa mempresentasikan hasil diskusi kelompok } \\
\text { ke depan kelas }\end{array}$ & 86,90 & Sangat Baik \\
\hline $\begin{array}{l}\text { Siswa dan guru bersama-sama menyimpulkan } \\
\text { materi yang dipelajari pada pembelajaran ini }\end{array}$ & 90,93 & Sangat Baik \\
\hline \multicolumn{3}{|l|}{ Online } \\
\hline $\begin{array}{l}\text { Siswa mengunggah hasil akhir diskusi presentasi } \\
\text { dan simpulan hasil pembelajaran ke blog guru }\end{array}$ & 75,82 & Baik \\
\hline Rata-Rata & 86,35 & Sangat Baik \\
\hline
\end{tabular}

Berdasarkan rata-rata kemampuan literasi sains siswa di dua sekolah dasar negeri, siswa memiliki kemampuan literasi sains dengan kategori baik, hal ini dapat menggambarkan bahwa proses pembelajaran blended learning dengan blog dapat melatih keterampilanketerampilan proses sains sehingga siswa terbiasa melakukan hal-hal yang berhubungan dengan 
kegiatan literasi sains diantaranya adalah mengidentifikasi pertanyaan ilmiah, memberikan penjelaskan fenomena secara ilmiah dan menggunakan bukti ilmiah. Pembelajaran blended learning dengan blog menggabungkan pembelajaran tatap muka dengan pembelajaran online. Pembelajaran tatap muka dengan blended learning berbasis nature of sains (NOS) yakni pembelajaran yang menerapkan langkah-langkah pembelajaran NOS dengan dukungan media pembelajaran berupa aplikasi-aplikasi pembelajaran online yang dapat dilakukan oleh siswa yang mendukung proses pembelajaran. Pembelajaran online berupa pembelajaran dengan blog yang berisi modul interaktif, bahan ajar, latihan soal yang dapat digunakan oleh guru dan siswa baik di dalam maupun di luar kelas. Agar kemampuan literasi sains dapat meningkat dengan baik, maka guru dihimbau untuk mulai memperkenalkan dan membelajarkan materi dengan menggunakan berbagai strategi yang dapat melatih kemampuan literasi sains, antara lain membelajarkan materi melalui pembelajaran berbasis nature of sains (NOS) yang dikembangkan dengan teknologi yang dapat merangsang siswa untuk tertarik pada pembelajaran dan sekaligus berpikir tingkat tinggi.

Bawaneh (2011) menyatakan bahwa blended learning dapat meningkatkan performansi siswa. Blended learning yang mengkombinasikan metode tatap muka dan online learning dapat melibatkan siswa secara aktif dan memungkinkan siswa mendapat umpan balik. Senada dengan hal ini Graham (2005) menyatakan blended learning dapat meningkatkan pedagogi, akses dan fleksibilitas, serta efektivitas biaya. Bantala (2010) menyimpulkan bahwa pembelajaran menggunakan blended learning terbukti dapat meningkatkan kemampuan kognitif peserta diklat teknik jaringan komputer dasar. Blended learning dapat membuat kemandirian siswa dan lebih efisien waktu. Lebih lanjut, penelitian yang dilakukan oleh Kusairi (2013) menyatakan bahwa pembelajaran blended learning mampu meningkatkan penguasaan konsep dan penalaran siswa. Sedangkan pembelajaran NoS dapat dimaknai sebagai hakikat Ilmu Pengetahuan Alam yaitu merujuk kepada karakteristik ilmu pengetahuan itu sendiri. Hakikat IPA mempelajari tentang ilmu pengetahuan alam melalui metode ilmiah dengan menanamkan nilai-nilai etos saintis. Secara umum Mercado, Macayana, \& Urbiztondo (2015) menjelaskan bahwa NoS mengacu pada kuncinya prinsip dan ide yang memberikan deskripsi sains yang valid sebagai cara untuk mengetahui serta karakteristik pengembangan pengetahuan ilmiah mengandung empat hal, yaitu: konten atau produk, proses atau metode, sikap dan teknologi. Mattew (2017) menyatakan bahwa NoS merupakan epistemologi dari sains, sains sebagai cara untuk memperoleh pengetahuan, atau nilai-nilai dan keyakinankeyakinan yang melekat pada pengetahuan ilmiah atau pada pengembangan kemampuan literasi sains. Sebagaimana yang disampaikan Zuriani (2012) bahwa pembelajaran blended learning berbasis NOS mengembangkan kemampuan literasi sains siswa melalui kegiatan-kegiatan mengobservasi, merumuskan pertanyaan yang relevan, mengevaluasi buku dan sumber-sumber informasi lain secara kritis, merencanakan penyelidikan atau investigasi, mereview apa yang telah diketahui, melaksanakan percobaan atau eksperimen dengan menggunakan alat untuk memperoleh data, menganalisis dan menginterpretasi data, serta membuat prediksi dan mengkomunikasikan hasilnya dengan bantuan alat dan teknologi digital seperti blog, website maupun media sosial saat ini dengan menggabungkan pembelajaran online dan tatap muka.

\section{SIMPULAN}

Pembelajaran blended learning dengan blog yakni pembelajaran yang menerapkan langkahlangkah pembelajaran tatap muka berbasis nature of sains (NOS) dan pembelajaran online dengan dukungan media pembelajaran berupa blog yang dapat diterapkan di proses pembelajaran. Blog tersebut berisi bahan ajar yang bisa digunakan oleh guru dan siswa baik di dalam maupun di luar kelas. Tahapan kegiatan pembelajaran ini mengembangkan kemampuan literasi sains siswa melalui kegiatan membaca konteks pada artikel di blog, tanya jawab mendalam, observasi, demonstrasi prosedur, penelusuran pustaka, melaksanakan prosedur, mengkomunikasikan pengetahuan sains. Kemampuan literasi sains siswa pada setiap aspeknya berada pada kategori berbeda-beda yaitu (1) berada pada kategori baik adalah aspek kreatif, sosial, metode ilmiah, komunikasi dan kolaborasi, dan etos. (2) berada pada kategori cukup adalah tentatif, teori dan hukum, dan empiris. Secara umum rata-rata kemampuan literasi sains siswa berada pada kategori baik (74,86\%). Adapun rata-rata kemampuan literasi sains siswa di dua sekolah negeri berada pada kategori baik. Respon siswa 
terhadap pembelajaran blended learning dengan blog berada pada kategori sangat baik $(86,35 \%)$.

\section{DAFTAR PUSTAKA}

Afandi, Junanto, \& Afriani. Implementasi DigitalAge Literacy dalam Pendidikan Abad 21 di Indonesia. Paper presented at the Prosiding SNPS (Seminar Nasional Pendidikan Sains), 2016.

Albion, Peter. "Web 2.0 In Teacher Education: Two Imperatives for Action". Computers in the Schools, Vol.25, no.3 (2008):181-198.

Alexander, Laurel. Education \& Training On The Internet. An essensial resources for students, teachers and education providers. Internet Handbook. UK, 2000.

Alistya. Model pembelajaran blended learning dengan menggunakan media Moodle pada pembelajaran IPA terpadu dengan tema Pelestarian Lingkungan menunjukkan peningkatan kemampuan literasi sains siswa. Skripsi Tidak Dipublikasikan, Universitas Sebelas Maret, 2014.

Alwan. "Penerapan model pembelajaran blended learning dengan aplikasi edmodo pada siswa kelas XI melalui peningkatan literasi sains siswa". Biodidaktika, Vol.1, no.2 (2017) : 34-49.

Bantala, A.P. Penerapan E-Learning (Learning Management System) untuk Meningkatkan Kemampuan Kognitif Peserta Diklat Teknik Jaringan Komputer Dasar di PPPPTK Bmti Bandung. Tesis Jurusan Pendidikan Teknologi dan Kejuruan UPI. Bandung: PPs UPI, 2010.

Bawaneh. The Effects of Blended Learning Approach on Students' Performance: Evidence from A Computerized Accounting Course. Interdisciplinary Journal of Research in Business Vol. 1, Issue. 4, April (2011):43-50

Becker \& Park. "Integrative Approaches among Science Technology, Engineering, and Mathematics (STEM) Subject on Students Learning: Meta-Analysis". Journal of STEM Education: Innovation and Research, Vol.12, no.5 (2011):23.

Bell."Project Based Learning for the 21th Century: Skills for the Future".The Clearing House, Vol. 83 (2010): 39.

Buckner \& Kim. Integrating technology and pedagogy for inquiry- based learning: The
Stanford Mobile Inquiry-based Learning Environment Prospects Quarterly Review, 2013

Driscoll, M. "Blended Learning: Let's Get beyond the Hype". IBM Global Services, 2002.

Geraldin, Monalisa. Pengaruh Model Pembelajaran dan Kemampuan Berpikir Kritis Terhadap Kemampuan Literasi Sains Siswa. Jakarta: Universitas Negeri Jakarta, 2015.

Graham, Allen, S., Ure, D. (2005). Beneits and challenges of blended learning environments. In M. Khosrow-Pour (Ed.), Encyclopedia of information science and technology I- $V$. Hershey, PA: Idea Group Inc.

Izzudin, Syarif. "Pengaruh model blended learning terhadap motivasi dan prestasi belajar siswa SMK". Jurnal Pendidikan Vokasi,Vol 2,no.2 (2002): 234-244.

Kusairi. Implementasi Blended Learning. Malang: Program Studi Pendidikan Fisika FMIPA UM, 2012.

Lukman, Yusakhiril, Hadi Suwono, Endang Suarsini. Implementasi model pembelajaran blended learning dengan memadukan pembelajaran tatap muka di kelas dan secara online menggunakan e-learning dapat meningkatkan kemandirian belajar dan literasi sains siswa. Tesis Tidak Dipublikasikan, Universitas Negeri Jakarta, 2017.

Matthews, M.R. Reconceptualizing the Nature of Science for Science Education. Studies in Science Education Vol.5, no.3 (2017): 1057.

Mercado, C.T., Frienzky, B.M, \& Lorna, G.U. Examining Education Students Nature of Science Views. Asia Pacific Journal of Multidisciplinary Research vol.3, no.5 (2015): 101-10.

OECD. PISA 2012 Results in Focus What 15year-olds know and what they can do with what they knowh, 2012.

Thurlow,et al. Computer Mediated Communication -Social Interaction and The Internet: Sage Publication, 2004.

\section{Internet}

Zuriyani. Literasi Sains dan Pendidikan. 2016. (http://sumsel. kemenag.go.id), diakses 7 Januari 2019. 